\title{
Physicochemical Changes of Apple (Malus domestica) Fruit Cultivars as Influenced by Maturity Stages and Postharvest Management Practices
}

\author{
Tadesse Fikre Teferra ${ }^{1}$ and Eden Leka Lencha ${ }^{1}$ \\ ${ }^{I}$ School of Nutrition, Food Science and Technology, College of Agriculture, Hawassa University, Ethiopia \\ tadessefikre@gmail.comortadessefikre@hu.edu.et
}

\begin{abstract}
This research was conducted to understand changes of physicochemical properties of fruits of three apple cultivars as influenced by stage of maturity and packaging types over storage period of three weeks. The research was designed to replicate practices by the producers and along the value chains and to assess the fruit quality under the conditions of the major markets in the region. All the measured physicochemical parameters significantly varied with the cultivars, maturity stage at harvest and packaging types. Higher firmness was recorded for the samples harvested about two weeks before the optimal maturity, usually practiced by significant number of producers to gain market advantage. Lower total soluble solids corresponded to the early harvested samples regardless of cultivars and packaging types. The firmness was observed decreasing over the storage periods whereas the total soluble solids increased, which is associated to improving sensorial quality for the early harvested cultivars as the soluble solids are mainly sugars. The early harvesting resulted in fruits of inferior desirability including extreme hardness, firmness and low total soluble solids that may have high sourness and less sweet taste. Awareness creation for the producers on the quality and advantages of harvesting their produces at optimal maturity and practicing good postharvest management is required.
\end{abstract}

Key words: Postharvest storage, fruit firmness, total soluble solids, apple cultivars, apple packaging, apple maturity.

\section{Introduction}

Apple (Malus domestica) is one of the most valuable temperate climate fruits that is reportedly originated in many parts of Euro-Asia (Fetena et al., 2014). Apple is valued for its nutritional quality, sensorial crispy texture and citrusy sweet and sour taste. China has been the largest global producer (over $40 \%$ ) of different cultivars of apple followed by the United States (Shen et al., 2018). For the current production year (2019), China has still been the leading producer with 41.39 million metric tons (FAO, 2019). Apple and other pome fruits also play important nutritional and economic roles in tropical areas of Africa and the rest of the world, particularly in cool highland regions. The postharvest losses of horticultural crops, however, is reportedly limiting the economic relevance of horticultural crops in Sub-Saharan Africa (Affognon et al., 2015; Johnston et al., 2002).

Cultivation of different cultivars of apple in the highlands of Chencha and Sidama (Southern Regions) and Bale and Eastern Hararghe areas (Oromia Region) of Ethiopia has been significant over the last decades. Generally, apple can be appealing to up to $70 \%$ of Ethiopians, as they reside in the highland areas of the country (Girmay et al., 2014), where apple production can be feasible from agro climatology view-points, although in depth study may be required for specific areas. Chencha has traditionally been the major and famous apple producing area in Ethiopia since its introduction in the 1950s, by the British Protestant Missionaries (Girmay et al., 2014). Chencha 
contributes about 30\% (15 metric tons) of annual apple production in Ethiopia. Apple is the most valuable highland fruits in the Ethiopian farming systems, fetching 2-3 times the process of other tropical fruits produced in the country (Girmay et al., 2014).

The major challenges associated with the production and value chains of many of the horticultural produces in developing countries (including Sub-Saharan Africa) is the postharvest losses that reaches 50 to $60 \%$ depending on the crop type, postharvest handling practices, season and geographic locations (Asrat et al., 2019; Yahia et al., 2019). There are only few researches done to estimate the levels of apple postharvest losses in Chencha area, Ethiopia (Behailu and Kebede, 2018). It was found from our preliminary survey that postharvest losses of apple are high in Ethiopia, particularly in Chencha (the main production area) due to poor handling during harvesting, transportation and retail marketing. The other issue associated with apple harvesting is the fact that farmers harvest immature fruits to sale before the market is saturated and prices go down. There are also inconsistencies in the use of appropriate packaging materials. In this research, physicochemical changes in three popular apple cultivars produced in Chencha and harvested at two maturity stages were investigated over storage periods of three weeks. The different maturity levels and packaging types have been set based on the information obtained from a preliminary survey that involved producers themselves and agricultural extension agents. The major objective of the study was to establish the influences of the existing postharvest practices on apple postharvest quality.

\section{Materials and Methods}

\section{Sample collection and preparation}

About $20 \mathrm{~kg}$ fruits of three cultivars of apples (Bondred, Crisp and Jonagold) were harvested from randomly selected representative trees at two maturity stages. The first-round harvest was made at early maturity stages ( 2 weeks earlier than optimal maturity to replicate the practices of the farmers) and the second was harvested two weeks later at the optimal maturity based on the harvesting calendars obtained from the producers' cooperative unions and district officers. The harvesting was done in the morning at the time of least field heat period of the day. The harvested samples were then, gently packaged into plastic crates and covered to avoid exposure to the sun and transported under adequate ventilation to the city of Hawassa, which is one of the nearby domestic market destinations. The samples were cleaned and divided into two lots, one of which was packaged in a sealed thick polyethylene (PE) bags and the other remained in the plastic crates, exactly the same way the retailers handle in the markets. The samples were stored at room temperatures $\left(25 \pm 2^{\circ} \mathrm{C}\right)$ with physicochemical measurements done at a week time interval over three weeks or until the samples are spoiled to the level they have no market value.

\section{Physicochemical measurements}

\section{Fruit firmness}

Fruit firmness is the most desirable texture sensorial properties in apple (Costa et al., 2011; Hosoya et al., 2017) that is most studied in fresh fruit marketing and storage management. The method explained by Costa et al. (2011) was used for the firmness measurement with minor modifications. The force $(\mathrm{g})$ required to penetrate the fleshy part of the fruits was measured on three randomly 
selected apples using a Texture Profile Analyzer (Texture Analyzer (LLOYD Instruments, TA plus Ametek, UK 2007)) with a $5 \mathrm{~kg}$ load cell and a cylindrical flat head probe with a diameter of $4 \mathrm{~mm}$, a test speed of $300 \mathrm{~mm} / \mathrm{min}$ and auto force trigger of $5 \mathrm{~g}$.

\section{Total soluble solids}

A destructive method of total soluble solids content (Brix) determination was used. Random fruit samples (two fruits per session) were selected and blended into a juice. The juice was filtered using Whatman filter paper (number 1). Two drops of the filtrate were applied on the prism of a handheld refractometer (Atago, Japan) and measurements were done in triplicates (Hoehn et al., 2003).

\section{Titratable acidity and $\mathrm{pH}$ levels}

Juice was extracted from apple fruits and the beverage filtered using muslin cloth. Five milliliters of filtrate were dissolved in distilled water until the volume reached $50 \mathrm{~mL}$. Five milliliters aliquot of the sample solution was taken and titrated with $0.1 \mathrm{~N} \mathrm{NaOH}$ using phenolphthalein solutions as indicator until persistent pink color of indicator appeared. Triplicate measurement was taken and titratable acidity (\%) was calculated using the following formula (Xu et al., 2012).

$$
\% \text { Acidity }=\frac{V_{l} \mathrm{NaOH} \times 0.64 \times \mathrm{NNaOH}}{\text { SampleWeig } h t} \times 100
$$

Two apple fruits were taken randomly and macerated for juice and $50 \mathrm{~mL}$ extraction was centrifuged for 15 minutes. The $\mathrm{pH}$ of the extracted juice from the different cultivars, harvested at the different maturity, packaged in either PE bags or plastic crates were measured in triplicates. The $\mathrm{pH}$ meter was calibrated using a solution of 4.0 and $7.0 \mathrm{pH}$ levels (Symphony, SB420, USA). The $\mathrm{pH}$ electrode was thoroughly washed with distilled water in between the measurements.

\section{Weight loss}

The weight loss (g) of apples were measured using a digital balance at the beginning and in a week interval until the end of the experimentation. The changes in the weight from the previous week were recorded and analyzed for the different cultivars harvested at two maturity stages, packaged and stored at room temperature. The weight loss measurement was done in triplicates and over the entire storage study periods.

\section{Experimental set up and data analysis}

The experiment was arranged into a factorial completely randomized design (CRD) of $3 \times 2 \times 2$, where 3 apple cultivars were harvested at two maturity stages (early versus optimal) and packaged into polyethylene bags versus plastic crates all in three replications. The measured physicochemical parameters were analyzed using a three-way analysis of variance (ANOVA) using JMP statistical software (version 13) of the SAS Company. For the significant ANOVAs, mean separation was carried out using Fisher's least significant difference (LSD) and Tukey's honestly significant difference (HSD) procedures. Least square means were reported with standard errors. Correlation analysis was also employed between some of the measured responses. 


\section{Results and Discussions}

\section{Effects of maturity, variety and packaging on the physicochemical properties of apples}

\section{Maturity stages}

The different maturity stages of apples resulted in significantly varying firmness, total soluble solids (TSS), pH, titratable acidity (TA) and average weight losses (Fig. 1). Apple samples that were harvested 2 weeks earlier than the optimal maturity were observed to have significantly higher firmness (184.88 g, Fig. 1[A]), lower TSS (13.12 ${ }^{\circ} \mathrm{Bx}$, Fig. 1[B], pH (3.55) and average weight loss (1.68 g) (Fig. 1[C]) were recorded for the early harvested samples compared to those harvested at optimal maturity. The vast majority of total soluble solids in apple are soluble sugars that gives the fruits a sweet taste (Wei et al., 2020). Higher titratable acidity also corresponded to the lower $\mathrm{pH}$ of the early harvested samples in all the three cultivars packaged in both plastic crates and polyethylene bags. The higher firmness is due to the immature tissues of the fruit flesh, that is reportedly associated to the types of pectin fraction in the tissues whereas the concentrations of cellulose and hemicellulose structures remains unchanged with maturity and softening (Johnston et al., 2002). Similar trends were reported earlier for the different maturity levels of various cultivars (Jan et al., 2012). Early harvesting, which is mostly practiced by the farmers, resulted in apple fruits of poorer quality (higher acidity and firmer texture). 

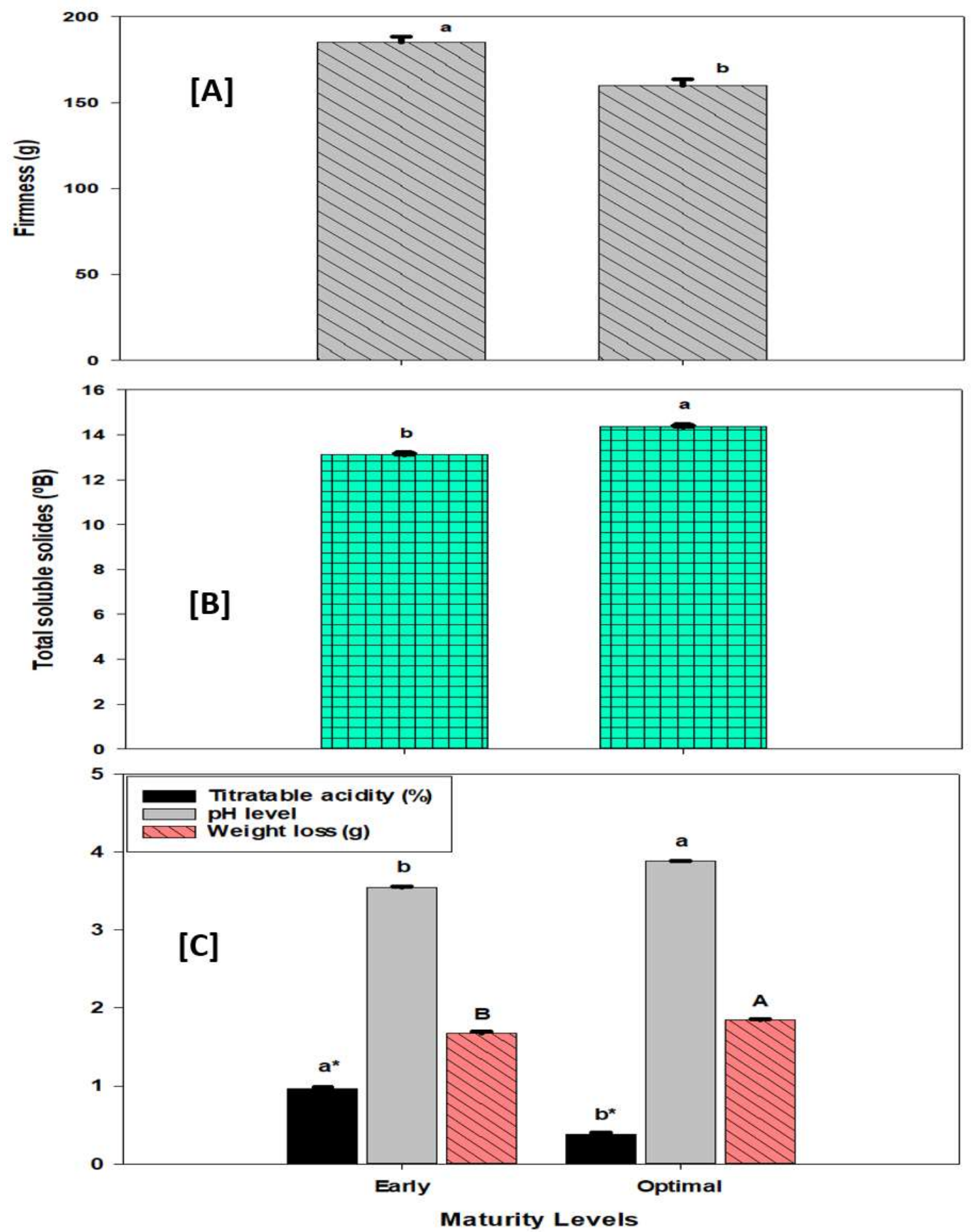

Figure 1. Apple fruits harvested at different maturity stages exhibited varying firmness [A], total soluble solids [B] and other physicochemical properties [C]. Values are least square means and error bars are standard errors of means.

The lower TSS also indicates lower sugar level that again limits the sweetness of the fruits. The lower average weight loss in the early harvested fruits might be due to limited metabolic and 
transpiration rates due to limited maturity of the fruits. Similar trends of TSS levels by maturity stages were reported earlier for common fruits including wax apple (Khandaker et al., 2018).

\section{Cultivars}

The three cultivars tested exhibited significantly different responses (Fig. 2). The Crisp cultivar had the highest firmness (183.74 g) and TSS (14.69 $\left.{ }^{\circ} \mathrm{Bx}\right)$ (Fig. 2 [A] \& [B]). The higher firmness might be due to the better water holding capacity by the higher TSS, that gave it a turgid behavior. Crisp also exhibited the highest average weight loss (1.93 g) compared to the other two cultivars. The Crisp cultivar has naturally green fruits that makes it difficult to judge the maturity level and that may result in higher quality and postharvest losses. Jonagold showed the least firmness and significantly higher TSS level than the Bondred cultivar. The least $\mathrm{pH}$ and highest TA were observed for the Jonagold cultivar, which also exhibited the least average weight loss compared to the other two. The ranges reported in the current work are in agreement for Jonagold and other apple cultivars reported recently (Zhang et al., 2019).

The difference in the cell structures and compositions of the different apple cultivars might have resulted in the different firmness, TSS levels and other physicochemical properties observed in the current research. Physical characteristics such as resistance to puncture as an indicator of susceptibility to microbial decays measured for various apple cultivars showed significant differences (Spotts et al., 1999). Different apple cultivars tested for an acoustic impulse treatment as non-destructive indices of fruit flesh firmness and TSS exhibited various responses (Zude et al., 2006), which agrees with the findings of the current work. 


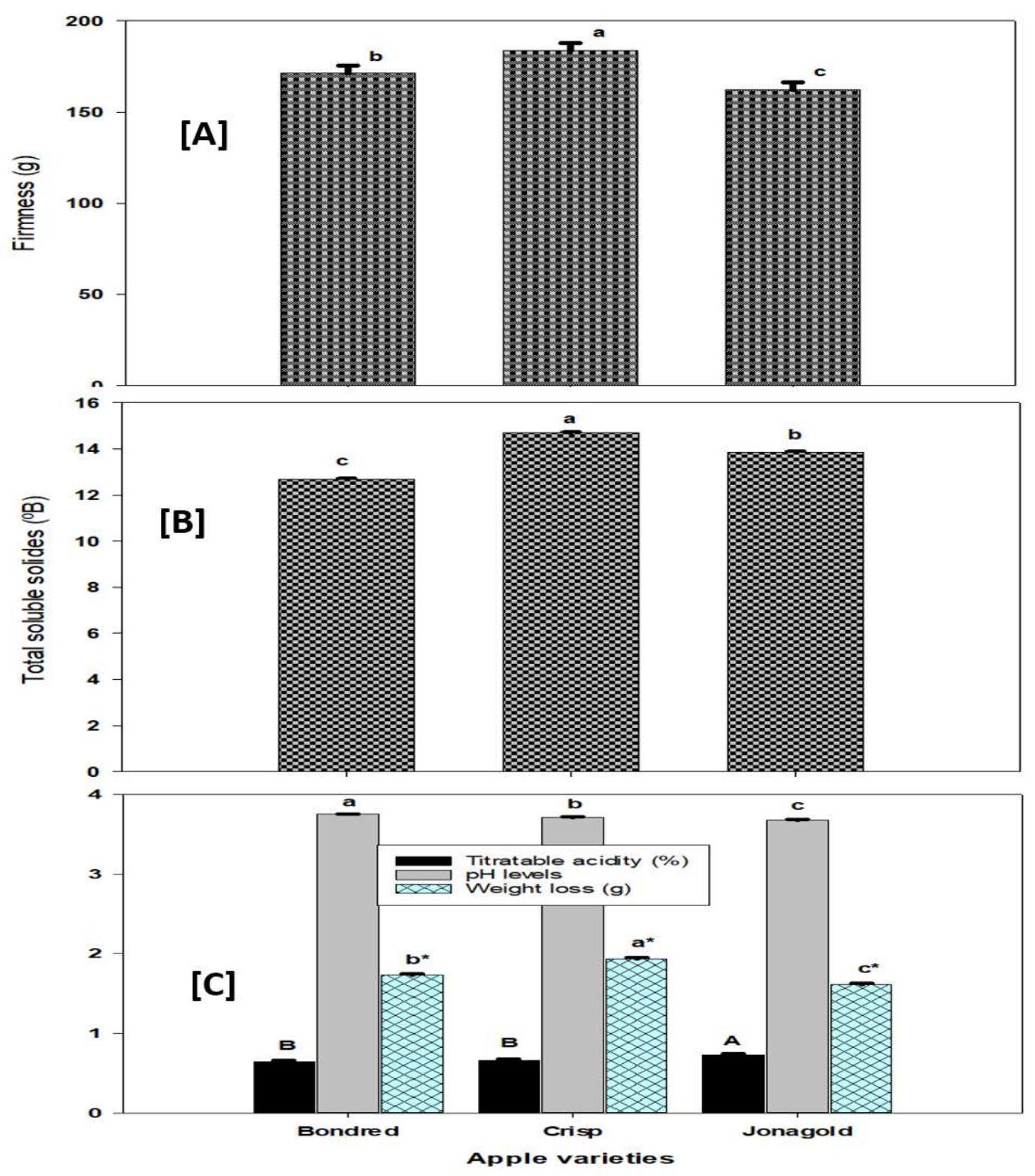

Figure 2. Different Apple cultivars exhibited varying firmness [A], total soluble solids [B] and other physicochemical properties [C]. Values are least square means and error bars are standard errors of means.

The implication of the observation from the current work might be that different apple cultivars need varying postharvest management practices to maintain their freshness. It also means that different cultivars may perform differently under different environmental conditions such as ambient temperature and relative humidity levels. Considerations of retailing the different cultivars for different markets might be crucial in markets like Ethiopia, where the cold chain management of horticultural crops is almost at the level of non-existence. Accordingly, the more turgid Crisp variety with significantly higher TSS may be marketed in warm and humid rift valley areas like 
Hawassa, whereas Bondred and Jonagold may be distributed to the central highland areas like Addis Ababa central market, although an in-depth study involving more growing areas is required to get to a more conclusive decision. Development of cold chain management is a lasting solution for maintenance of fruit freshness and should be considered for long term effective apple value chains.

\section{Packaging types}

The different packaging types tested in the current work, resulted in significantly $(\mathrm{p}<0.05)$ different physicochemical properties of apple fruits regardless of cultivars and maturity stages (Fig. 3). Packaging in plastic crates resulted in fruits of lower firmness (161.49 g, Fig. 3 [A]), higher TSS (14.33 ${ }^{\circ} \mathrm{Bx}$, Fig. $\left.3[\mathrm{~B}]\right)$ as well as lower pH levels (3.70, Fig. $\left.3[\mathrm{C}]\right)$ compared to the fruits packaged in polyethylene bags. The lower firmness, higher TSS and $\mathrm{pH}$ levels observed for the samples packaged in open plastic crates is likely due to faster transpiration rates that resulted in faster softening and decaying, as reported by Ngcobo et al. (2012) for table grapes. Packaging the apple fruits in polyethylene bags of different marketing sizes before putting in crates, might help to maintain their freshness particularly when marketing in warmer areas. 

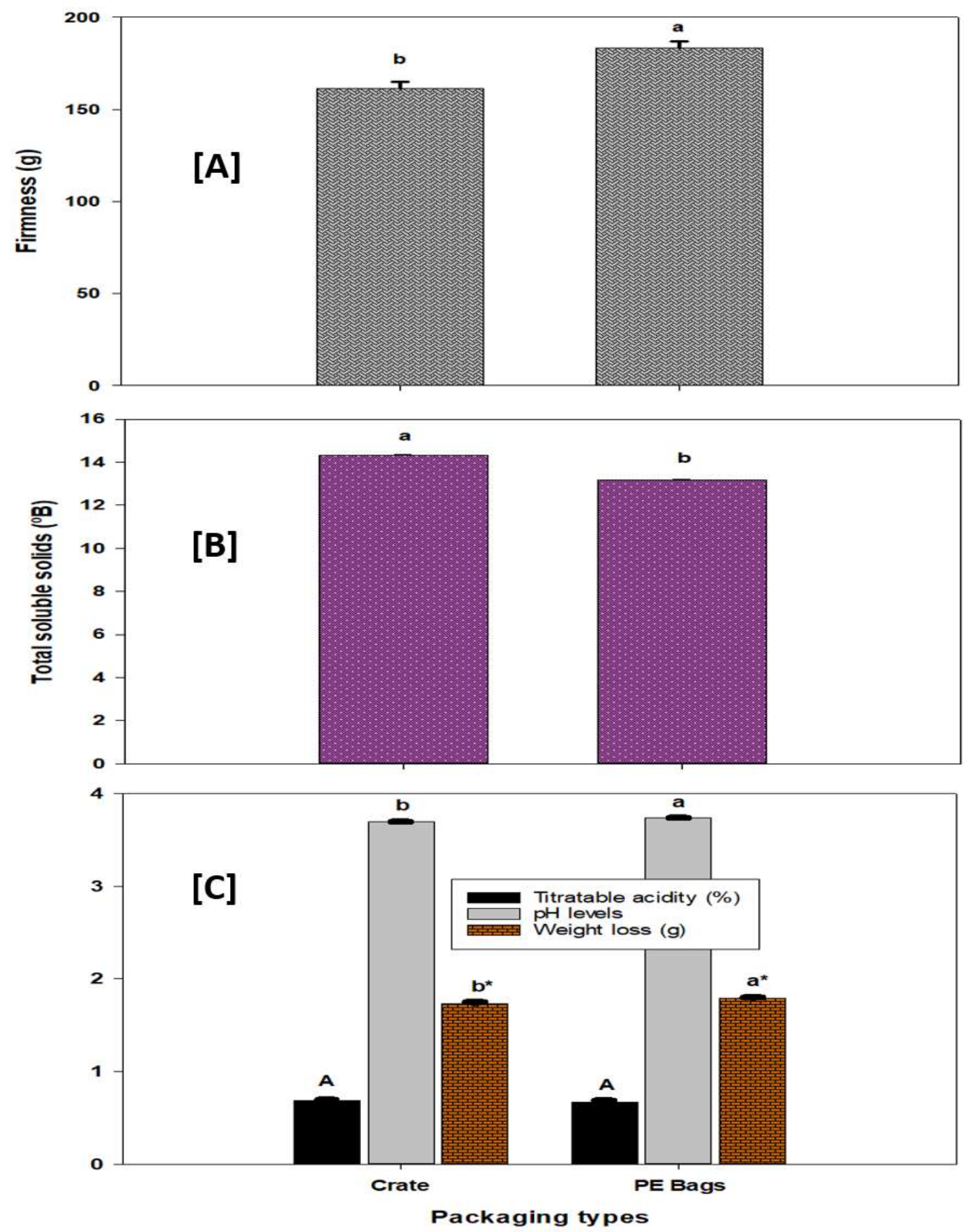

Figure 3. Apple fruit samples packaged in polyethylene bags and plastic crates exhibited varying firmness [A], total soluble solids [B] and other physicochemical properties [C]. Values are least square means and error bars are standard errors of means. 


\section{Combined effects of maturity levels for cultivars under various packages}

The different cultivars harvested at varying maturity stages exhibited significantly different physicochemical properties (Tables 1). The highest firmness $(194 \mathrm{~g})$ and the least TSS $\left(11.68^{\circ} \mathrm{B}\right)$ was observed for the early harvested Bondred cultivar, whereas the least firmness (149 g) and highest TSS $\left(15.09^{\circ} \mathrm{B}\right)$ corresponded to Bondred and Crisp cultivars, respectively both harvested at the optimal maturity. Jonagold harvested at early maturity exhibited the highest titratable acidity $(1.02 \%)$, the least $\mathrm{pH}(3.52)$ and weight loss levels. This is associated with inferior sensorial quality of the fruit harvested at early stages, which is always practiced by significant number of farmers with the belief of benefiting from the market before others.

Table 1: Combined (two-way interaction) effects of maturity stages, cultivars and packaging types in the physicochemical properties of apples.

\begin{tabular}{lccccc}
\hline Variables & Firmness $(\mathrm{g})$ & $\mathrm{TA}(\%)$ & $\mathrm{pH}$ & $\mathrm{TSS}\left({ }^{\mathrm{o} B x}\right)$ & Weight loss $(\mathrm{g})$ \\
\hline Maturity by variety & & & & & \\
Early, Bondred & $194^{\mathrm{a}}$ & $0.92^{\mathrm{b}}$ & $3.51^{\mathrm{e}}$ & $11.68^{\mathrm{e}}$ & $1.70^{\mathrm{c}}$ \\
Early, Crisp & $189^{\mathrm{a}}$ & $0.96^{\mathrm{ab}}$ & $3.62^{\mathrm{d}}$ & $14.30^{\mathrm{b}}$ & $1.83^{\mathrm{b}}$ \\
Early, Jonagold & $172^{\mathrm{abc}}$ & $1.02^{\mathrm{a}}$ & $3.52^{\mathrm{e}}$ & $13.37^{\mathrm{d}}$ & $1.51^{\mathrm{d}}$ \\
Optimal, Bondred & $149^{\mathrm{c}}$ & $0.36^{\mathrm{c}}$ & $4.00^{\mathrm{a}}$ & $13.69^{\mathrm{c}}$ & $1.77^{\mathrm{bc}}$ \\
Optimal, Crisp & $178^{\mathrm{ab}}$ & $0.36^{\mathrm{c}}$ & $3.81^{\mathrm{c}}$ & $15.09^{\mathrm{a}}$ & $2.04^{\mathrm{a}}$ \\
Optimal, Jonagold & $153^{\mathrm{bc}}$ & $0.43^{\mathrm{c}}$ & $3.84^{\mathrm{b}}$ & $14.34^{\mathrm{b}}$ & $1.73^{\mathrm{c}}$ \\
SE & 5.96 & 0.024 & 0.006 & 0.056 & 0.025 \\
Maturity by packaging & & & & & \\
Early, Crate & $173^{\mathrm{b}}$ & $1.00^{\mathrm{a}}$ & $3.50^{\mathrm{d}}$ & $13.77^{\mathrm{b}}$ & $1.61^{\mathrm{c}}$ \\
Early, PE Bags & $197^{\mathrm{a}}$ & $0.93^{\mathrm{a}}$ & $3.60^{\mathrm{c}}$ & $12.46^{\mathrm{c}}$ & $1.75^{\mathrm{b}}$ \\
Optimal, Crate & $150^{\mathrm{c}}$ & $0.36^{\mathrm{b}}$ & $3.89^{\mathrm{a}}$ & $14.89^{\mathrm{a}}$ & $1.86^{\mathrm{a}}$ \\
Optimal, PE Bags & $171^{\mathrm{b}}$ & $0.40^{\mathrm{b}}$ & $3.88^{\mathrm{b}}$ & $13.86^{\mathrm{b}}$ & $1.83^{\mathrm{a}}$ \\
SE & 4.87 & 0.019 & 0.005 & 0.046 & 0.021 \\
Variety by packaging & & & & & \\
Bondred, Crate & $146^{\mathrm{d}}$ & $0.63^{\mathrm{b}}$ & $3.74^{\mathrm{b}}$ & $13.03^{\mathrm{d}}$ & $1.74^{\mathrm{b}}$ \\
Bondred, PE Bags & $197^{\mathrm{a}}$ & $0.65^{\mathrm{ab}}$ & $3.77^{\mathrm{a}}$ & $12.33^{\mathrm{e}}$ & $1.73^{\mathrm{b}}$ \\
Crisp, Crate & $182^{\mathrm{abc}}$ & $0.69^{\mathrm{ab}}$ & $3.67^{\mathrm{c}}$ & $15.44^{\mathrm{a}}$ & $1.88^{\mathrm{a}}$ \\
Crisp, PE Bags & $186^{\mathrm{ab}}$ & $0.63^{\mathrm{ab}}$ & $3.76^{\mathrm{a}}$ & $13.94^{\mathrm{c}}$ & $1.99^{\mathrm{a}}$ \\
Jonagold, Crate & $157^{\mathrm{cd}}$ & $0.73^{\mathrm{a}}$ & $3.68^{\mathrm{c}}$ & $14.51^{\mathrm{b}}$ & $1.59^{\mathrm{c}}$ \\
Jonagold, PE Bags & $168^{\mathrm{bcd}}$ & $0.72^{\mathrm{ab}}$ & $3.68^{\mathrm{c}}$ & $13.20^{\mathrm{d}}$ & $1.64^{\mathrm{bc}}$ \\
SE & 5.96 & 0.02 & 0.006 & 0.056 & 0.025 \\
\hline
\end{tabular}

Values are least square means and those with different superscript letters in the same columns under the same variable combinations are significantly different; TA = titratable acidity; $T S S=$ total soluble solids; $S E=$ standard errors

The early harvested remained significantly firmer when packaged in the PE bags than when stored in plastic crates without packaging with the bags. The early harvested samples packed in PE bags had the highest firmness (197 g) and the least TSS $\left(12.46^{\circ} \mathrm{B}\right)$, compared to the same stored in plastic crates. The plastic crate storage might help the fruits to transpire at a higher rate with the supply of oxygen, that lead to significant maturity and softening (Ngcobo et al., 2012). Looking at the packaging types for the different cultivars of apples, the highest firmness (197 $\mathrm{g})$ and the least TSS $\left(12.33^{\circ} \mathrm{B}\right)$ corresponded to the Bondred cultivar regardless of the maturity levels, 
although that wasn't significantly different from Crisp cultivars regardless of the packaging types (182 and $186 \mathrm{~g}$, for crates and PE bags respectively).

Looking at the three-way interaction of the apple cultivars, maturity level and packaging types, significantly different physicochemical properties were observed. Early harvested samples packaged in the PE bags had higher firmness and lower TSS, regardless of the cultivar types, compared to optimally matured counterparts and those packaged in plastic crates. The result implies that the early harvested samples packaged in PE bags had less desirability in terms of texture (firmness), TSS and other parameters measured (Table 2). This means that the early harvesting and $\mathrm{PE}$ bag packaging practice of the producers for early marketing is resulting in fruits of inferior quality and desirability. Our claim is supported by earlier reports (Anzueto and Rizvi, 1985; Putnik et al., 2017), that revealed that different packaging types and treatments have shown influences on the postharvest quality of apple cultivars in earlier works. The result is evident that the apple value chain in Chencha, the largest and oldest highland fruit pocket in the country, suffers low quality due to improper harvesting and postharvest handling practices.

Table 2: Combined (three-way interaction) effects of maturity stages, cultivars and packaging types in the physicochemical properties of apples.

\begin{tabular}{lccccc}
\hline Maturity*Cultivars*Packaging & Firmness (g) & TA (\%) & pH & TSS $\left({ }^{\circ} \mathrm{Bx}\right)$ & Weight loss (g) \\
\hline Early, Bondred, Crate & $173^{\mathrm{bc}}$ & $0.91^{\mathrm{ab}}$ & $3.47 \mathrm{a}$ & $12.16^{\mathrm{g}}$ & $1.64^{\mathrm{def}}$ \\
Early, Bondred, PE Bags & $215^{\mathrm{a}}$ & $0.93^{\mathrm{ab}}$ & $3.54^{\mathrm{a}}$ & $11.19^{\mathrm{h}}$ & $1.76^{\mathrm{cd}}$ \\
Early, Crisp, Crate & $179^{\mathrm{abc}}$ & $1.02^{\mathrm{ab}}$ & $3.56^{\mathrm{b}}$ & $15.15^{\mathrm{b}}$ & $1.72^{\mathrm{cd}}$ \\
Early, Crisp, PE Bags & $200^{\mathrm{ab}}$ & $0.90^{\mathrm{b}}$ & $3.68^{\mathrm{c}}$ & $13.46^{\mathrm{e}}$ & $1.94^{\mathrm{ab}}$ \\
Early, Jonagold, Crate & $168^{\mathrm{bc}}$ & $1.07^{\mathrm{a}}$ & $3.47^{\mathrm{d}}$ & $14.01^{\mathrm{d}}$ & $1.48^{\mathrm{ef}}$ \\
Early, Jonagold, PE Bags & $175^{\mathrm{abc}}$ & $0.98^{\mathrm{ab}}$ & $3.57^{\mathrm{d}}$ & $12.73^{\mathrm{f}}$ & $1.53^{\mathrm{ef}}$ \\
Optimal, Bondred, Crate & $118^{\mathrm{d}}$ & $0.34^{\mathrm{c}}$ & $4.01^{\mathrm{e}}$ & $13.90^{\mathrm{d}}$ & $1.83^{\mathrm{bc}}$ \\
Optimal, Bondred, PE Bags & $180^{\mathrm{abc}}$ & $0.38^{\mathrm{c}}$ & $3.99^{\mathrm{f}}$ & $13.48^{\mathrm{e}}$ & $1.71^{\mathrm{cd}}$ \\
Optimal, Crisp, Crate & $184^{\mathrm{abc}}$ & $0.35^{\mathrm{c}}$ & $3.78^{\mathrm{f}}$ & $15.75^{\mathrm{a}}$ & $2.04^{\mathrm{a}}$ \\
Optimal, Crisp, PE Bags & $172^{\mathrm{bc}}$ & $0.37^{\mathrm{c}}$ & $3.85^{\mathrm{f}}$ & $14.43^{\mathrm{c}}$ & $2.03^{\mathrm{a}}$ \\
Optimal, Jonagold, Crate & $147^{\mathrm{cd}}$ & $0.39^{\mathrm{c}}$ & $3.90^{\mathrm{g}}$ & $15.01^{\mathrm{b}}$ & $1.70^{\mathrm{cde}}$ \\
Optimal, Jonagold, PE Bags & $160^{\mathrm{bc}}$ & $0.47^{\mathrm{c}}$ & $3.78^{\mathrm{g}}$ & $13.68^{\mathrm{de}}$ & $1.76^{\mathrm{d}}$ \\
SE & 11.9 & 0.05 & 0.011 & 0.113 & 0.050 \\
\hline
\end{tabular}

Values are least square means and those with different superscript letters in the same columns under the same variable combinations are significantly different; TA = titratable acidity; TSS = total soluble solids; $S E=$ standard errors

\section{Physicochemical changes over storage}

Significant changes in the physicochemical characteristics of the apples were obtained over the storage time of 3 weeks at room temperature (Fig. 4). The firmness of the apples was decreasing over the storage period (Fig. 4 [A]) and in the meantime the TSS was increasing (Fig. 4[B]). The decreasing firmness and increasing TSS over the storage time, was also supported by a weak but significant negative correlation $(\mathrm{r}=-0.43)$ ). This likely indicates that the pectin structural matrices are changing into soluble materials that results into softening of the fruit tissue and increasing soluble materials. Major portion of the TSS is soluble sugars such as fructose, glucose and sucrose (Wei et al., 2020) and the increase in their levels may improve the fruit taste mainly in the early 
harvested samples. The softening phenomena over the storage periods may slightly improve the texture and flavor of the early harvested fruits, but is an undesirable softening for the ones harvested at the optimal maturity as it is associated with cell wall modifying enzymes and ethylene production that leads to senescence (Ortiz et al., 2011; Storch et al., 2015). Ranges of the parameters obtained and the trends observed over storage period were reported in earlier studies (Jan et al., 2012; Watkins et al., 2000). The loss of firmness over storage at controlled temperature (lower) and controlled atmosphere, was explained to be caused by synthesis of pectin degrading enzymes and synthesis of ethylene (Gwanpua et al., 2012). Similarly, the softening of apple tissues on storage was reported to cause changes in sensory and instrumental texture profiles (Oraguzie et al., 2009).

There were also changes in the other physicochemical properties like titratable acidity (\%) and $\mathrm{pH}$ of the fruits. The $\mathrm{pH}$ of the fruits was observed increasing when the TA was decreasing, although there was no consistent and steady change over the different weeks (Fig. $4[\mathrm{C}]$ ). The increasing pH with the decreasing TA was also supported by a weak but significant negative correlation $(\mathrm{r}=$ 0.40) which is also supported by trends reported in the literature (Ignat et al., 2014). The overall changes in the physicochemical properties of apple fruits over the storage periods of three weeks, indicate losses in desirability of the fruits over storage. On the contrary, there might be some improvement in the texture and tests of the early harvested apples samples, as these were extremely hard (firm) during the first week after harvesting. 


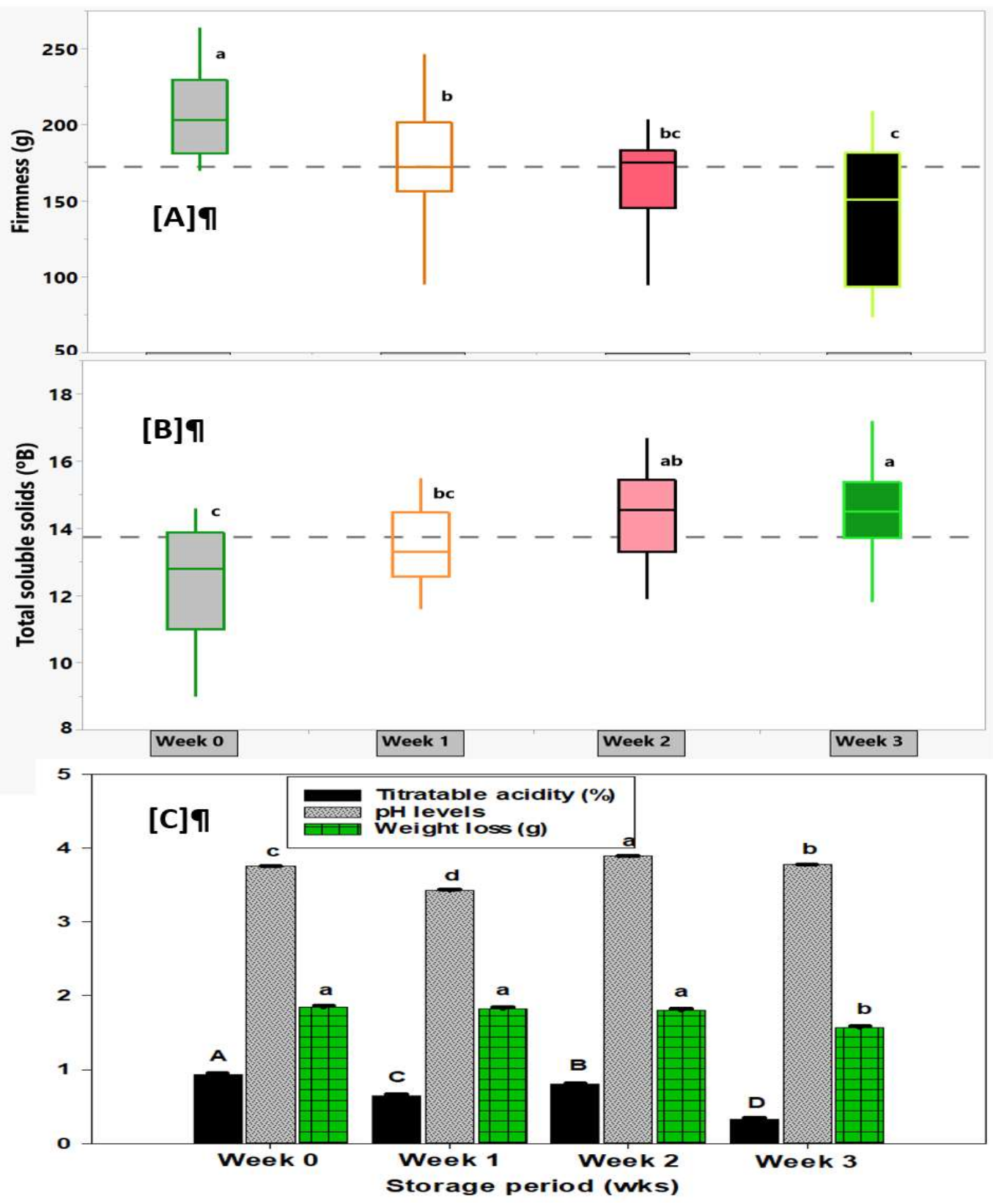

Figure 4. Apple fruit samples exhibited decreasing firmness [A], increasing total soluble solids $[B]$ and variable other physicochemical properties $[\mathrm{C}]$ over storage. Values are least square means and error bars are standard errors of means.

Generally, the decreasing firmness might improve the textural properties of the early harvested samples over storage time. Faster change in firmness was observed for the samples packaged in the plastic crates compared to the ones packaged in PE bags. Therefore, it seems apparent that the early harvested samples, although discouraged, may fit for the plastic crate bulk packaging while the ones harvested at the optimal maturity may be packaged in PE bags to slow the softening due 
to senescence. The increasing TSS accompanying decreasing firmness levels, might be taken as an improvement in the sweetness of the fruit flesh, particularly for the early harvested, as the higher proportion of the TSS are sugars. The maturity stages at harvest and packaging types used can be combined to help the producers and actors of apple value chains maximize their fruit quality and for the market needs. Similar trends were reported in literatures for apples of different cultivars and other common fruits (Anzueto and Rizvi, 1985; Ngcobo et al., 2012; Putnik et al., 2017).

\section{Conclusions}

The firmness, total soluble solids and other physicochemical properties of different apple cultivars harvested at two maturity stages and stored under two packaging types exhibited significantly varying storage performances over a storage period of 3 weeks. The early harvested apples were firm and may not be sensorial as desirable compared to those harvested at optimal maturity. Fruit firmness decreased over the three weeks' storage time at room temperature, while the total soluble solids kept increasing, which showed degradation of the pectin structural components while increasing soluble components. Plastic crates showed better changes in the texture of the early harvested samples, but PE bags might perform better for the optimally harvested fruits by slowing the softening and senescence of the tissues. However, awareness creation among the apple producers and also exercising of some sorts of quality control by the local governments may be required to change the practices and benefit all actors of apple value chain.

\section{Acknowledgements}

The authors appreciate the financial support from the SNV project funded by The Netherlands Development Organizations. The facilitation by Holleta Research Center of the Ethiopian Institute of Agricultural Research is also acknowledged. Technical support by Dr. Abadi Gebre Mezgebe at the beginning of the proposal development is acknowledged.

\section{References}

Affognon, H., Mutungi, C., Sanginga, P., Borgemeister, C., 2015. Unpacking postharvest losses in Sub-Saharan Africa: A Meta-Analysis. World Dev. 66, 49-68. https://doi.org/10.1016/j.worlddev.2014.08.002

Anzueto, C.R., Rizvi, S.S.H., 1985. Individual Packaging of Apples for Shelf Life Extension. J. Food Sci. 50, 897-900. https://doi.org/10.1111/j.1365-2621.1985.tb12975.x

Asrat, F., Ayalew, A., Degu, A., 2019. Postharvest Loss Assessment of Tomato (Solanum lycopersicum L.) in Fogera, Ethiopia. Turkish J. Agric. - Food Sci. Technol. 7, 1146. https://doi.org/10.24925/turjaf.v7i8.1146-1155.2460

Behailu, A., Kebede, J., 2018. Journal of Stored Products and Postharvest Research A study on the causes of apple (Malus Domestica) fruit loss at Chencha Woreda of Gamo Gofa Zone, Southern Ethiopia. J. Stored Prod. Postharvest Res. 9, 72-77.

Costa, F., Cappellin, L., Longhi, S., Guerra, W., Magnago, P., Porro, D., Soukoulis, C., Salvi, S., Velasco, R., Biasioli, F., Gasperi, F., 2011. Assessment of apple (Malus $\times$ domestica Borkh.) fruit texture by a combined acoustic-mechanical profiling strategy. Postharvest Biol. Technol. 61, 21-28. https://doi.org/10.1016/j.postharvbio.2011.02.006 
FAO, 2019. Food and Agricultural Organization of the United Nations Statistical Database, FAOSTAT statistics database.

Fetena, S., Shara, S., Anjulo, A., Gulie, G., Yilma, B., 2014. Survey on Apple Production and Variety Identification in Chencha District of Gamo Gofa Zone, Southern Ethiopia, J. Agric. Food. Tech.

Girmay, G., Menza, M., Mada, M., Abebe, T., 2014. Empirical Study on Apple Production, Marketing and its Contribution to Household Income in Chencha District of Southern Ethiopia. Sch. J. Agric. Sci. 4, 166-175.

Gwanpua, S.G., Verlinden, B.E., Hertog, M.L.A.T.M., Bulens, I., Van de Poel, B., Van Impe, J., Nicolaï, B.M., Geeraerd, A.H., 2012. Kinetic modeling of firmness breakdown in "Braeburn" apples stored under different controlled atmosphere conditions. Postharvest Biol. Technol. 67, 68-74. https://doi.org/10.1016/j.postharvbio.2011.12.010

Hoehn, E., Gasser, F., Guggenbühl, B., Künsch, U., 2003. Efficacy of instrumental measurements for determination of minimum requirements of firmness, soluble solids, and acidity of several apple varieties in comparison to consumer expectations. Postharvest Biol. Technol. 27, 27-37. https://doi.org/10.1016/S0925-5214(02)00190-4

Hosoya, N., Mishima, M., Kajiwara, I., Maeda, S., 2017. Non-destructive firmness assessment of apples using a non-contact laser excitation system based on a laser-induced plasma shock wave. Postharvest Biol. Technol. 128, 11-17. https://doi.org/10.1016/j.postharvbio.2017.01.014

Ignat, T., Lurie, S., Nyasordzi, J., Ostrovsky, V., Egozi, H., Hoffman, A., Friedman, H., Weksler, A., Schmilovitch, Z., 2014. Forecast of Apple Internal Quality Indices at Harvest and During Storage by VIS-NIR Spectroscopy. Food Bioprocess Technol. 7, 2951-2961. https://doi.org/10.1007/s11947-014-1297-7

Jan, I., Rab, A., Sajid, M., Sajid, M., 2012. Storage performance of apple cultivars harvested at different stages of maturity. J. Anim. Plant Sci 22, 438.

Johnston, J.W., Hewett, E.W., Hertog, M.L.A.T.M., 2002. Postharvest softening of apple (Malus domestica) fruit: A review. New Zeal. J. Crop Hortic. Sci. https://doi.org/10.1080/01140671.2002.9514210

Khandaker, M.M., Amirah, F.N., Majrashi, A., Sajili, M.H., Mohd, K.S., Mat, N., 2018. Peel colour, anthocyanin, TSS content and sensory evaluation of some common fruits: A comparative study. Aust. J. Crop Sci. 12, 1788-1795. https://doi.org/10.21475/ajcs.18.12.11.p1489

Ngcobo, M.E.K., Delele, M.A., Pathare, P.B., Chen, L., Opara, U.L., Meyer, C.J., 2012. Moisture loss characteristics of fresh table grapes packed in different film liners during cold storage. Biosyst. Eng. 113, 363-370. https://doi.org/10.1016/j.biosystemseng.2012.09.011

Oraguzie, N., Alspach, P., Volz, R., Whitworth, C., Ranatunga, C., Weskett, R., Harker, R., 2009. Postharvest assessment of fruit quality parameters in apple using both instruments and an expert panel. Postharvest Biol. Technol. 52, 279-287. https://doi.org/10.1016/j.postharvbio.2009.01.004

Ortiz, A., Graell, J., Lara, I., 2011. Cell wall-modifying enzymes and firmness loss in ripening "Golden Reinders" apples: A comparison between calcium dips and ULO storage. Food Chem. 128, 1072-1079. https://doi.org/10.1016/j.foodchem.2011.04.016

Putnik, P., Bursać Kovačević, D., Herceg, K., Levaj, B., 2017. Influence of Cultivar, AntiBrowning Solutions, Packaging Gasses, and Advanced Technology on Browning in FreshCut Apples During Storage. J. Food Process Eng. 40, e12400. 
https://doi.org/10.1111/jfpe. 12400

Shen, Y., Nie, J., Dong, Y., Kuang, L., Li, Y., Zhang, J., 2018. Compositional shifts in the surface fungal communities of apple fruits during cold storage. Postharvest Biol. Technol. 144, 55-62. https://doi.org/10.1016/j.postharvbio.2018.05.005

Spotts, R.A., Cervantes, L.A., Mielke, E.A., 1999. Variability in postharvest decay among apple cultivars. Plant Dis. 83, 1051-1054. https://doi.org/10.1094/PDIS.1999.83.11.1051

Storch, T.T., Finatto, T., Pegoraro, C., Dal Cero, J., Laurens, F., Rombaldi, C.V., Quecini, V., Girardi, C.L., 2015. Ethylene-dependent regulation of an $\alpha$-l-arabinofuranosidase is associated to firmness loss in "Gala" apples under long term cold storage. Food Chem. 182, 111-119. https://doi.org/10.1016/j.foodchem.2015.02.123

Watkins, C.B., Nock, J.F., Whitaker, B.D., 2000. Responses of early, mid and late season apple cultivars to postharvest application of 1-methylcyclopropene (1-MCP) under air and controlled atmosphere storage conditions. Postharvest Biol. Technol. 19, 17-32. https://doi.org/10.1016/S0925-5214(00)00070-3

Wei, K., Ma, C., Sun, K., Liu, Q., Zhao, N., Sun, Y., Tu, K., Pan, L., 2020. Relationship between optical properties and soluble sugar contents of apple flesh during storage. Postharvest Biol. Technol. 159. https://doi.org/10.1016/j.postharvbio.2019.111021

Xu, K., Wang, A., Brown, S., 2012. Genetic characterization of the Ma locus with $\mathrm{pH}$ and titratable acidity in apple. Mol. Breed. 30, 899-912. https://doi.org/10.1007/s11032-0119674-7

Yahia, E.M., Fonseca, J.M., Kitinoja, L., 2019. Postharvest Losses and Waste, in: Postharvest Technology of Perishable Horticultural Commodities. Elsevier, pp. 43-69. https://doi.org/10.1016/b978-0-12-813276-0.00002-x

Zhang, Y., Nock, J.F., Al Shoffe, Y., Watkins, C.B., 2019. Non-destructive prediction of soluble solids and dry matter contents in eight apple cultivars using near-infrared spectroscopy. Postharvest Biol. Technol. 151, 111-118. https://doi.org/10.1016/j.postharvbio.2019.01.009

Zude, M., Herold, B., Roger, J.M., Bellon-Maurel, V., Landahl, S., 2006. Non-destructive tests on the prediction of apple fruit flesh firmness and soluble solids content on tree and in shelf life. J. Food Eng. 77, 254-260. https://doi.org/10.1016/j.jfoodeng.2005.06.027 